\title{
THE impact of remittance inflows on poverty in Botswana: an ARDL approach
}

\author{
Mercy. T. Musakwa* and N. M. Odhiambo
}

*Correspondence:

tsile.musa@gmail.com

Department of Economics,

University of South Africa

(UNISA), P.O Box 392,

Pretoria 0003, South Africa

\begin{abstract}
The growing pressure on governments to reduce poverty among other Sustainable Development Goals (SDGs) through harnessing domestic and foreign sources has motivated studies on the relationship between poverty and different economic variables in many developing countries. This study investigates the impact of remittance on poverty in Botswana, employing time-series data from 1980 to 2017. The study employs two poverty proxies - household consumption expenditure and infant mortality rate to capture poverty in its multidimensional form and improve the robustness of the results. Using the autoregressive distributed lag (ARDL) approach, the study finds that remittance inflows reduce poverty in Botswana-both in the short run and in the long run when infant mortality rate is used as a proxy. However, when poverty is measured by household consumption expenditure, remittance was found to have no impact on poverty in the short run and in the long run. The study, therefore, concludes that remittance inflows play a crucial role in reducing poverty and that Botswana can benefit immensely from the surge in remittance inflows by putting in place policies and structures that support remittance inflow.
\end{abstract}

Keywords: Remittance, Poverty, Household consumption expenditure, Infant mortality rate, Botswana, ECM-based causality testing

JEL Classification: F24, 131

\section{Introduction}

The growing need to find a solution to poverty alleviation has resulted in heightened interest from researchers to find the most important economic variable that could serve as a panacea to poverty alleviation. Consequently, the surge in remittance inflows globally, in general, and in low and middle-income countries, in particular, has ignited studies focused on the establishment of the nature of the relationship between remittance and poverty. According to Migration Policy Institute (2019), the global monetary transfers from migrants reached $\$ 689$ billion in 2018 with remittance inflows to low and middle-income countries, taking $77 \%$ of the global transfer. The monetary transfers to low and middle-income countries are expected to grow by $\$ 21$ billion in 2019 and projected to reach $\$ 550$ billion (Migration Policy Institute 2019). Remittance has grown to be an important source of foreign income besides foreign direct investment and official development assistance (ODA) (Ratha et al. 2018). 
Despite the existence of extensive literature on the remittance-poverty nexus, the associated results are far from being conclusive. Some studies found remittance to support economic growth (Lim and Simmons 2015; Meyer and Shera 2017; Makun 2018), while other studies found remittance to have an insignificant impact (Adam and Klobodu 2016). Among the studies that investigated the impact of remittance on poverty, some found remittance to reduce poverty (see Adam and Page 2005; Adam and Cuecuacha 2013; Vacaflores 2018). Some studies found remittance to have no impact on poverty, implying that low and middle-income countries may not reduce poverty through remittance inflows (see, for example, Azam et al. (2016). A few studies have taken a step further to investigate the causal relationship between remittance and poverty (see, for example, Abdulnasser and Salah 2014; Gaaliche and Gaaliche 2014; Yasman et al. 2015) and found the relationship between the two inconclusive as well. Given the inconclusiveness of the results, it would be inappropriate to generalise results from one country across other countries. It is against this background that the current study aims to examine the relationship between remittance inflows and poverty in Botswana-using timeseries data from 1980 to 2017.

Although to date researchers are still debating on the best poverty measure, with some advocating for a multidimensional measure as the best poverty measure, no agreement has been reached. Taking this raging debate into account, this study employs two poverty proxies, namely household consumption expenditure and infant mortality rate. Household consumption expenditure measures income poverty, while infant mortality rate captures health poverty. Although there are other indexes that could be used to measure poverty in a multidimensional form, such as the human development index, such measures could not be used in the current study due to insufficient time-series data. The same applies to other income poverty measures, such as poverty headcount, poverty gap and poverty gap squared.

The rest of the study is divided into five sections as follows: Sect. 2 outlines the literature review; Sect. 3 discusses estimation techniques; Sect. 4 presents and discusses the results; and Sect. 5 concludes the study.

\section{Remittance and poverty dynamics in Botswana}

Botswana was a signatory to the Sustainable Development Goals (SDGs) for 2030 at the United Nations Sustainable Development Summit in 2015; a successor to the Millennium Development Goals that concluded in September 2015 (United Nations 2019). This move exhibited commitment by Botswana in working with other countries to meet the 17 SDGs (United Nations 2019). Section 10.c.1 gives remittance special attention and focuses on reducing the transaction cost of remittance to less than 3\% (United Nations 2019). In addition to the SGDs, Botswana is also a signatory ILO Migrant Workers Convention, 1990 UN Migrant Workers Convention and 2002 Migrant Smuggling Protocol (United Nations Children's Emergency Funds UNICEF 2019). The ability of the Botswana government to harness diamond resources and channel it towards development has left most Batswana contended to work and stay in the home country (Migration Policy Institute 2004). Given the surge in remittance inflows in low and middle-income countries, another study on the relationship between remittance and poverty in the case of Botswana will shed more light on the nature of the relationship. 
Botswana recorded the highest remittance inflows of $8 \%$ were recorded in the 1980 s (United Nations Conference on Trade and Development UNCTAD 2019). During this period, many Batswana citizens were immigrating to South Africa in search of greener pastures in gold and diamond mines (Migration Policy Institute 2004). Thereafter, there was a gradual fall in remittance inflows throughout the 1990s and 2000s (UNCTAD 2019). An average remittance inflow of $1.4 \%$ was registered between 1990 and 2000, which is $1 \%$ higher than an average of $0.4 \%$ between 2000 and 2017 (UNCTAD 2019). The depressed remittance inflow is contrary to the general increases in remittance inflows recorded globally.

On the poverty front, there has been a gradual reduction in poverty when measured by metrics, such as human development index (HDI), poverty headcount, income held by the lowest $20 \%$ of the population, and poverty gap (World Bank 2019). Poverty headcount at $\$ 3.20$ poverty line was at $63.8 \%$, while poverty headcount at $\$ 1.90$ poverty line was at $42.6 \%$ in 1985 (World Bank 2019). The poverty headcount declined to $38.5 \%$ and $16.1 \%$ in 2015 for $\$ 3.20$ and $\$ 1.90$ poverty lines, respectively (World Bank 2019). The same trend is reflected in the poverty depth, where $13.8 \%$ was recorded in 2015 for $\$ 3.20$ poverty line, a fall from $32.6 \%$ in 1985 (World Bank 2019). Based on the $\$ 1.90$ poverty line, there was a fall in poverty depth from $17.9 \%$ in 1985 to $4.3 \%$ in 1985 (World Bank 2019). The income held by the bottom 20\% declined further in 1993 to 3\% from 3.6\% recorded in 1985 (World Bank 2019). A slight improvement of 0.9\% was registered in 2015 to give a share of 3.9\% (World Bank 2019). The statistics suggest Botswana income distribution is unequal as evidenced by contrasting income held by the highest $20 \%$ of the population that registered $58.9 \%$ in 1985 before increasing to $64.9 \%$ in 1993 and declining to $58.5 \%$ in 2015 (World Bank, 2019). The improvement in poverty is also reflected in the composite index-the human development index (HDI) that recorded 0.58 in 1990 and improved to 0.72 in 2017 (United Nations Development Programme 'UNDP', 2019).

\section{Review of related literature}

Theoretical literature suggests a positive relationship between remittance and poverty reduction. Although remittance has the potential to reduce poverty, according to HagenZanker and Himmelstine (2016), migration is not for the poor in society due to the cost associated with the move. Theoretical literature that focuses on the relationship between remittance and poverty can be split into two, one category that supports a positive direct relationship (see De Vries 2011; Hagen-Zanker and Himmelstine 2016) and the other category that supports an indirect relationship (see for example Ratha 2007). Remittances are a unique form of foreign income that reaches a greater share of the overall population in comparison to other forms of transfers (Hagen-Zanker and Himmelstine 2016). Further, remittances reach both male and female recipients compared to targeted cash transfers that are selective (Duflo and Hendry 2004).

According to Adam and Page (2005), remittances are associated with investment in human capital and cash assets. Ratha (2007) also added real estate and support to small businesses. Most importantly, remittance inflows provide a stable and counter-cyclical income, especially during social shocks-like wars and drought (Kapur 2004). Ratha (2007) further suggests an indirect positive impact of remittance on poverty reduction 
realised through the multiplier effect which is initiated by an increase in consumption and investment. This leads to improved living standards-a reflection of poverty reduction.

The burgeoning inflow of remittances, coupled with the need to reduce poverty, has created a lot of attention among researchers on if remittance can be a solution to poverty reduction. This has resulted in a number of studies that explored the nature of the relationship in different countries. Unlike the theoretical literature where the relationship between poverty and remittance is largely poverty mitigating, empirical research is far from being conclusive. Among the studies that attempted to establish the relationship between poverty and remittance, the results largely reflect a positive relationship (Adam and Page 2005; Acosta 2008; Gupta et al. 2009; Fuente 2010; Anyanwu and Erhijakpan 2010; Adam and Cuecuacha 2013; Akobeng 2016; Nahar and Arshad 2017; Vacaflores 2018; Tsaurai 2018). However, there are other studies that found the relationship to be dependent on the country of study, methodology and time under investigation (Azam et al. 2016; Wangle and Devkota 2018).

Adam and Page (2005) in a study on 71 developing countries investigated the impact of remittance on poverty. Employing poverty headcount and poverty gap as poverty proxies, remittance was found to mitigate poverty. A $10 \%$ increase in per capita international remittance was found to lead to a $3 \%$ reduction in people living in poverty. Acosta (2008) analysed the impact of remittances on poverty in Latin America using 59 industrial developing countries from 1970 to 2000. Like findings from Adam and Page (2005), remittance was found to reduce poverty.

Gupta et al. (2009) investigated the impact of remittance in 76 countries. In the study, a $10 \%$ increase in remittances was found to result in a $1 \%$ decrease in poverty headcount and poverty gap. In the same spirit, Anyanwu and Erhijakpan (2010) studied the impact of remittance on poverty using panel data from 33 African countries from 1990 to 2005 . A $10 \%$ increase in international remittance was found to result in a $2.9 \%$ decrease in poverty headcount. Similar to the findings by Adam and Page (2005) and Gupta et al. (2009) and Anyanwu and Erhijakpan (2010), Fuente (2010) found remittance to reduce poverty in Mexico using data from 1998 to 2000. Adam and Cuecuacha (2013) also analysed the impact of remittance on poverty in Ghana. The findings from the study were consistent with Fuente (2010) and Gupta et al. (2009).

Akobeng (2016) investigated the impact of remittance on poverty and inequality using microdata from sub-Saharan Africa and found remittance to reduce poverty. In a similar vein, Nahar and Arshad (2017) investigated the impact of remittance on poverty reduction in Indonesia employing data from 1983 to 2015 and also found remittance to reduce poverty. Vacaflores (2018) also studied the impact of remittance on poverty using panel data from 2000 to 2012 from 19 Latin American countries. In the study, remittance was found to mitigate poverty. Tsaurai (2018), in a separate study on selected emerging market economies, found remittance to reduce poverty.

Azam et al. (2016) investigated the impact of remittance on poverty reduction in 39 lower-middle, upper-middle and high-income countries employing panel data. Remittance was found to have a positive impact on poverty reduction in upper-middle-income countries with a $1 \%$ increase in remittance, leading to a $0.2 \%$ reduction in poverty. In the same study, remittance was found to be insignificant in high-income countries. The 
findings from this study show that the impact of remittance on poverty is sensitive to the country under study; hence, the results from one country cannot be generalised to another country. Wangle and Devkota (2018) investigated the impact of remittance on poverty using longitudinal panel survey data from 1996 to 2017 for Nepal. Remittance was found to reduce poverty, although the results were sensitive to the time frame and poverty variable used. Based on the studies reviewed, the poverty reduction effect of remittance inflows is largely supported in the literature. However, findings from studies like Azam et al. (2016), and Wangle and Devkota (2018) suggest the importance of a country-specific study on the relationship between remittance and poverty.

\section{Methodology}

This study employs autoregressive distributed lag (ARDL) bounds testing approach to investigate the impact of remittance on poverty in Botswana. The ARDL approach has been selected for this study because of a number of advantages that include among other advantages: robustness in small samples (Solarin and Shahbaz 2013); the approach does not require all variables to be integrated of the same order before further analysis is done (Pesaran et al. 2001:290); and the ARDL bounds testing approach provides unbiased estimates of the long-run model, even when the variables are endogenous (Odhiambo 2009a, b). Based on the advantages that the ARDL approach offers when it comes to data analysis, this approach has been selected.

\subsection{Variables}

The main variables of interest in this study are poverty, measured by household consumption expenditure (HHC), infant mortality rate (INFA) and remittance inflows (REM). Two poverty proxies have been selected to capture poverty in its multidimensional form and to improve the robustness of the results. Household consumption expenditure is expressed as a percentage of GDP, and the infant mortality rate captures the number of infant deaths per 1000 live births. Household consumption expenditure captures income poverty, and infant mortality rate captures health poverty. In the literature, household consumption expenditure has been used to capture poverty (see, for example, Ravallion 2001; Odhiambo 2009a, b; Kaidi et al. 2018). A positive relationship between household consumption expenditure and remittance means remittance reduce poverty, while a negative relationship implies remittance worsen poverty. There are other studies in the literature that have used infant mortality rate as a proxy for poverty such as Van Multzahn and Durrheim (2008) and Abosedra et al. (2016). A negative relationship between infant mortality rate and remittance implies remittance helps in reducing poverty, while a positive relationship means remittance worsens poverty levels. Remittance is the main independent variable which is proxied by international remittance inflows expressed as a percentage of GDP. Expressing remittance as a percentage of GDP makes comparison across countries easier as it takes into account the remittance flows in relation to the size of the country. Remittance is expected to have a negative relationship with infant mortality rate and a positive relationship with household consumption expenditure.

Apart from remittance inflows, other control variables namely: education (EDU), trade openness (TOP), real gross domestic product per capita (GDPC) and inflation (INF) are 
included in the model. Education is captured by gross primary school enrolment rates. Education captures human capital, the ability of the poor to acquire knowledge, betterpaying jobs and to be trainable. A positive relationship between education and household consumption expenditure implies education is instrumental in reducing poverty, while a negative relationship between education and infant mortality rate implies that education mitigates poverty. Trade openness is a sum of exports and imports divided by GDP. Bharadwaj (2014) found trade openness to reduce poverty. A positive relationship between trade openness and household consumption expenditure means trade openness mitigate poverty, while a negative relationship between infant mortality rate and trade openness implies trade openness reduce poverty. Another control variables included in the models is real gross domestic product per capita (GDPC), which captures the level of living standards in Botswana, assuming an equal distribution of income. High real gross domestic product per capita implies a better living standard, which translates to low poverty levels. Nahar and Arshad (2017) also used real gross domestic product per capita as a control variable. Real gross domestic product per capita is expected to have a positive relationship with household consumption expenditure, while a negative relationship is expected between infant mortality rate and GDPC. Inflation (INF) is captured by the consumer price index (CPI). High inflation rate erodes the purchasing power of the poor putting them in a worse off position (Mohr and Fourie 2008, p. 480). Inflation is expected to have a negative effect on household consumption expenditure and a positive effect on infant mortality rate.

\subsection{Empirical model specification}

The model specification follows Adam and Page (2005) but differs on the variables included in the model. The general model specification is given in Eq. 1.

$$
\operatorname{Pov}_{\mathrm{mt}}=\alpha_{0}+\alpha_{1} \mathrm{REM}+\alpha_{2} \mathrm{EDU}+\alpha_{3} \mathrm{TOP}+\alpha_{4} \mathrm{GDPC}+\alpha_{5} \mathrm{INF}+\varepsilon_{t}
$$

where $\operatorname{Pov}_{\mathrm{m}}$ is household consumption expenditure or infant mortality rate. The two poverty proxies enter the equation one at a time, but the control variables remain the same.

The ARDL specification of the general empirical model in Eq. 1 can be expressed as:

$$
\begin{aligned}
\Delta \operatorname{Pov}_{\mathrm{mt}}= & \alpha_{0}+\sum_{i=1}^{n} \alpha_{1 i} \Delta \operatorname{Pov}_{\mathrm{mt}-i}+\sum_{i=0}^{n} \alpha_{2 i} \Delta \mathrm{REM}_{t-i}+\sum_{i=0}^{n} \alpha_{3 i} \Delta \mathrm{EDU}_{t-i}+\sum_{i=0}^{n} \alpha_{4 i} \Delta \mathrm{TOP}_{t-i} \\
& +\sum_{i=0}^{n} \alpha_{5 i} \Delta \mathrm{GDPC}_{t-i}+\sum_{i=0}^{n} \alpha_{6 i} \Delta \mathrm{INF}_{t-i}+\vartheta_{1} \operatorname{Pov}_{\mathrm{mt}-1}+\vartheta_{2} \mathrm{REM}_{t-1}+\vartheta_{3} \mathrm{EDU}_{t-1} \\
& +\vartheta_{4} \mathrm{TOP}_{t-1}+\vartheta_{5} \mathrm{GDPC}_{t-1}+\vartheta_{6} \mathrm{INF}_{t-1}+\mu_{1 t}
\end{aligned}
$$

where $\alpha_{0}$ is a constant; $\alpha_{1 i}-\alpha_{6 i}$ are short-run coefficients; $\vartheta_{1}-\vartheta_{6}$ are long-run coefficients; and $\mu_{1 t}$ is the white noise error term. The rest of the variables are as defined in Eq. 1.

The ARDL-based error correction model of the general empirical model is specified as follows: 


$$
\begin{aligned}
\Delta \operatorname{Pov}_{\mathrm{mt}}= & \alpha_{0}+\sum_{i=1}^{n} \alpha_{1 i} \Delta \operatorname{Pov}_{\mathrm{mt}-i}+\sum_{i=0}^{n} \alpha_{2 i} \Delta \mathrm{REM}_{t-i}+\sum_{i=0}^{n} \alpha_{3 i} \Delta \mathrm{EDU}_{t-i}+\sum_{i=0}^{n} \alpha_{4 i} \Delta \mathrm{TOP}_{t-i} \\
& +\sum_{i=0}^{n} \alpha_{5 i} \Delta \mathrm{GDPC}_{i-1}+\sum_{i=0}^{n} \alpha_{6 i} \Delta \mathrm{INF}_{t-i}+\gamma_{1 i} \mathrm{ECM}_{t-1}+\mu_{t}
\end{aligned}
$$

where $\alpha_{0}$ is a constant; $\alpha_{1 \mathrm{i}}-\alpha_{6 \mathrm{i}}$ are short-run coefficients; ECM is the error correction model and $\mu_{t}$ is the white noise error term. The rest of the variables are as defined in Eq. 1.

\subsection{Data sources}

The study uses annual time-series data from 1980 to 2017 to investigate the impact of remittance on poverty. The data on inflation (INF), infant mortality rate (INFA), household consumption expenditure (HHC), education (EDU), trade openness (TOP) and real gross domestic product per capita (GDPC) figures were extracted from the World Bank Development Indicators Database. Remittances (REM) were recorded from UNCTAD database. Microfit 5.0 was used to analyse the data.

\section{Empirical analysis}

\subsection{Unit root test}

The ARDL approach employed in this study does not require a unit root test; however, the test was done on all the variables included in the model to confirm that they are integrated of order 0 [I (0)] or 1 [I (1)]. The ARDL approach falls away if variables are integrated of order two (2) or higher. Table 1 presents the results of the unit root tests conducted using the Dickey-Fuller Generalised Least Square (DF-GLS), Perron (1997) and (PPURoot) tests.

The unit root results presented in Table 1 reveal that all variables are stationary in levels or first difference. This confirms the appropriateness of employing the ARDL bounds testing approach to infer on cointegration and ADRL regression analysis.

\subsection{Cointegration test}

Cointegration results for Model 1 and Model 2 are presented in Table 2.

Cointegration is confirmed in Model 1 and Model 2. The calculated F-statistics for Model 1 is 4.5551, and for Model 2 is 3.3728; which are higher than the critical values also presented in Table 2 critical values by Pesaran et al. (2001). This confirms a longrun relationship among the variables in both models-Model 1 and Model 2. To proceed with the analysis and establish the impact of remittance on poverty, an optimal lag length for Model 1 and Model 2 is selected using either Akaike information criteria (AIC) or Schwarz Bayesian criteria (SBC) depending on the most parsimonious model. The long-run and short-run results for Model 1 and Model 2 are presented in Table 3.

The results presented in Table 3, Panel A and Panel B, show that remittance has a negative impact on poverty in the short run and in the long run under Model 2 when infant mortality rate is used as a proxy of poverty (Pov2). These results are in line with findings from previous studies (see, Adam and Page 2005; Gupta et al., 2009; Anyanwu and Erhijakpan 2010; Nahar and Arshad 2017; Vacaflores 2018; Tsaurai 2018). The 


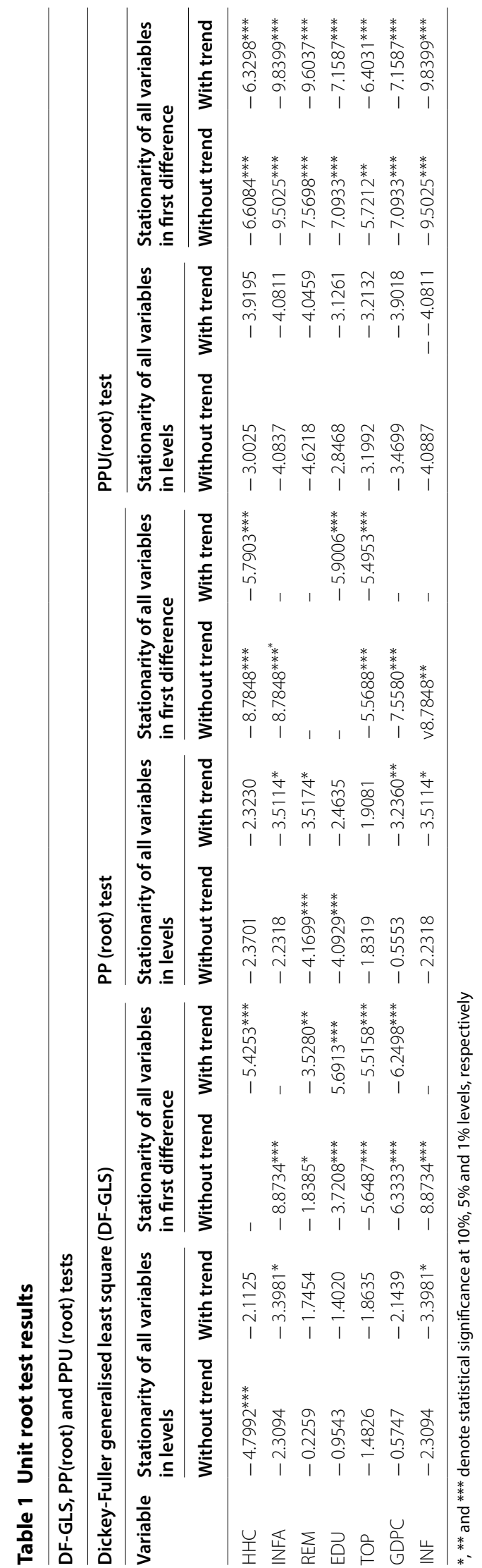


Table 2 ARDL approach to cointegration results

\begin{tabular}{|c|c|c|c|c|c|c|}
\hline Model & $\begin{array}{l}\text { Independent } \\
\text { variables }\end{array}$ & Function & F-statistic & Cointegration status & & \\
\hline 1 & $\mathrm{HHC}$ & $\begin{array}{l}\text { F(HHC|REM, EDU, TOP, } \\
\text { GDPC, INF) }\end{array}$ & $4.5551^{* *}$ & Cointegrated & & \\
\hline 2 & INFA & $\begin{array}{l}\text { F(INFA|REM, EDU, TOP, } \\
\text { GDPC, INF) }\end{array}$ & $3.3728^{*}$ & Cointegrated & & \\
\hline \multicolumn{7}{|c|}{ Asymptotic critical values (unrestricted intercept and no trend) } \\
\hline \multirow{3}{*}{$\begin{array}{l}\text { Pesaran et al. } \\
\text { (2001:300) critical } \\
\text { values (Table Cl(iii) } \\
\text { Case III) }\end{array}$} & $10 \%$ & & $5 \%$ & & $1 \%$ & \\
\hline & $\mathrm{I}(0)$ & $\mid(1)$ & $\mid(0)$ & $\mid(1)$ & $\mathrm{I}(0)$ & $\mathrm{I}(1)$ \\
\hline & 2.26 & 3.35 & 2.62 & 3.79 & 3.41 & 4.68 \\
\hline
\end{tabular}

*,** and ${ }^{* * *}$ denote statistical significance at $10 \%, 5 \%$ and $1 \%$ levels respectively

negative impact of remittance on poverty confirms that remittance inflows play a positive role in poverty alleviation in Botswana. Thus, Botswana can benefit from remittance inflows in the fight against poverty. Possible channels that Batswana can benefit from remittance are suggested by Ratha (2007) and De Vries (2011) as-investment in real estate, improvement in the fiscal position of a country through the balance of payment as additional benefits that are associated with remittance and small businesses growth. In addition, Kapur (2004) added remittances as a stable household income that has a countercyclical nature. However, in Model 1, when poverty is measured by household consumption expenditure, remittance is found to have no impact on poverty irrespective of the timing-short run or long run. This finding is not unique to Botswana alone. Azam et al. (2016) found the same results in a global study for upper-income countries.

Other results reported in Table 3 Panel A and Panel B when household consumption expenditure is used as a proxy for poverty (Model 1) show that: (i) education has an insignificant impact on poverty in Botswana in both the short run and the long run; (ii) trade openness has an insignificant impact on poverty in Botswana, and (iii) real gross domestic product has a positive impact on poverty reduction only in the long run; and (iv) inflation has a positive impact on poverty reduction in the long run.

Results reported in Panel A and Panel B of Table 3, where the infant mortality rate is used as a proxy for poverty (Model 2) show that: (i) education has a negative and significant impact on poverty in the short run only; (ii) trade openness has a positive impact on poverty in the short run and a negative and significant relationship at 10\% in the long run; (iii) real Gross domestic product per capita has a negative impact on infant mortality rate-i.e. it reduces poverty in both the short run and the long run; and (iv) inflation has a negative impact on infant mortality rate in the short run but not in the long run.

The following diagnostic tests were performed on Model 1 and Model 2-serial correlation, functional form, normality test and heteroscedasticity. Model 1 passed all diagnostic tests, while Model 2 passed serial correlation and heteroscedasticity but failed functional form and normality. However, upon inspection of the cumulative sum of recursive residuals (CUSUM) and cumulative sum of squares of recursive residuals (CUSUMSQ), the two models were found to be stable at 5\% level of significance. Diagnostic results are presented in Table 4, while the stability test results are reported in Fig. 1.

CUSUM and CUSUMQ results are presented in Fig. 1. 
Table 3 Empirical results for Model 1 and Model 2

\begin{tabular}{|c|c|c|c|c|}
\hline \multirow{2}{*}{$\begin{array}{l}\text { Model } \\
\text { Regressor }\end{array}$} & \multicolumn{2}{|c|}{$\begin{array}{l}\text { Model } 1 \text { (dependent variable is } \operatorname{Pov}_{1} \text { ) } \\
\text { ARDL }(1,0,0,1,1,4)\end{array}$} & \multicolumn{2}{|c|}{$\begin{array}{l}\text { Model } 2 \text { (dependent variable } \\
\left.\text { is } \operatorname{Pov}_{2}\right) \text { ARDL }(1,2,0,4,0,0)\end{array}$} \\
\hline & Coefficient & $T$-ratio & Coefficient & $T$-ratio \\
\hline \multicolumn{5}{|l|}{ Panel A: long-run results } \\
\hline C & -6.4197 & -0.8627 & $28.8387^{* * *}$ & 3.1448 \\
\hline REM & 0.2640 & 1.2726 & $-0.9203^{* * *}$ & -2.6184 \\
\hline EDU & 0.0704 & 0.0669 & 0.0150 & 0.1610 \\
\hline TOP & 0.08226 & 0.7392 & $-0.2470^{*}$ & -1.7717 \\
\hline GDPC & $0.4600^{* * *}$ & 3.3616 & $-0.5806^{* * *}$ & -4.2503 \\
\hline INF & $0.2189^{* * *}$ & 3.1606 & 0.0941 & -1.3528 \\
\hline \multicolumn{5}{|l|}{ Panel B (short run results) } \\
\hline$\triangle \mathrm{REM}$ & 0.1767 & 1.2292 & $-0.1065^{*}$ & -1.8216 \\
\hline$\triangle R E M(1)$ & - & - & 0.6212 & 1.1868 \\
\hline$\triangle \mathrm{EDU}$ & 0.0471 & 1.0778 & $-0.3880^{* * *}$ & -2.9532 \\
\hline$\triangle \mathrm{TOP}$ & 0.0292 & 0.3167 & 0.0031 & 0.1022 \\
\hline$\triangle \mathrm{TOP}(1)$ & - & - & 0.0291 & 0.7657 \\
\hline$\triangle \mathrm{TOP}(2)$ & - & - & 0.0344 & 0.8610 \\
\hline$\triangle \mathrm{TOP}(3)$ & - & - & 0.0145 & 0.3777 \\
\hline$\triangle \mathrm{TOP}(4)$ & - & - & $0.1268^{*}$ & 1.8764 \\
\hline$\triangle \mathrm{GDPC}$ & $-0.9614^{* * *}$ & -2.9360 & $-0.1265^{* *}$ & -2.5113 \\
\hline$\triangle \mathrm{GDPC}(1)$ & - & - & -0.2980 & -1.2242 \\
\hline$\triangle \mathrm{GDPC}(2)$ & - & - & -0.3385 & -1.3690 \\
\hline$\triangle I N F$ & -0.00545 & -0.1526 & $-0.2933^{*}$ & -1.7843 \\
\hline$\triangle I N F(1)$ & $-0.1725^{* * *}$ & -2.8378 & $-0.0204^{*}$ & 1.9327 \\
\hline$\triangle I N F(2)$ & -0.08232 & -1.6753 & - & - \\
\hline$\triangle I N F(3)$ & -0.0551 & -1.6603 & - & - \\
\hline \multirow[t]{2}{*}{$\operatorname{ECM}(-1)$} & $-0.6694^{* * *}$ & -4.0287 & $-0.2151^{* *}$ & -2.6423 \\
\hline & Model 1 & Model 2 & & \\
\hline$R$-squared & 0.6941 & 0.6148 & & \\
\hline$R$-bar-squared & 0.5198 & 0.3947 & & \\
\hline F-statistic & 5.2944 & 3.3576 & & \\
\hline Prob (F-statistic) & 0.001 & 0.008 & & \\
\hline DW statistic & 2.2458 & 1.8464 & & \\
\hline SE of regression & 0.3013 & 0.1015 & & \\
\hline Residual sum of squares & 1.9066 & 0.2165 & & \\
\hline Akaike info. criterion & -12.2658 & 24.7149 & & \\
\hline Schwartz Bayesian criterion & -22.1871 & 14.7936 & & \\
\hline
\end{tabular}

Note: ${ }^{*}, * *$ and ${ }^{* * *}$ denote statistical significance at $10 \%, 5 \%$ and $1 \%$ levels respectively

Table 4 Diagnostic Results for Models 1 and 2

\begin{tabular}{lll}
\hline LM test statistic & \multicolumn{2}{l}{ Results (probability) } \\
\cline { 2 - 3 } & Model 1 & Model 2 \\
\hline Serial correlation CHSQ (1) & $1.9821(0.159)$ & $0.2491(0.618)$ \\
Functional form CHSQ (1) & $1.1519(0.283)$ & $3.6804(0.055)$ \\
Normality CHSQ (1) & $0.7034(0.703)$ & $5.9481(0.051)$ \\
Heteroscedasticity CHSQ (1) & $0.9999(0.752)$ & $0.4154(0.984)$ \\
\hline
\end{tabular}




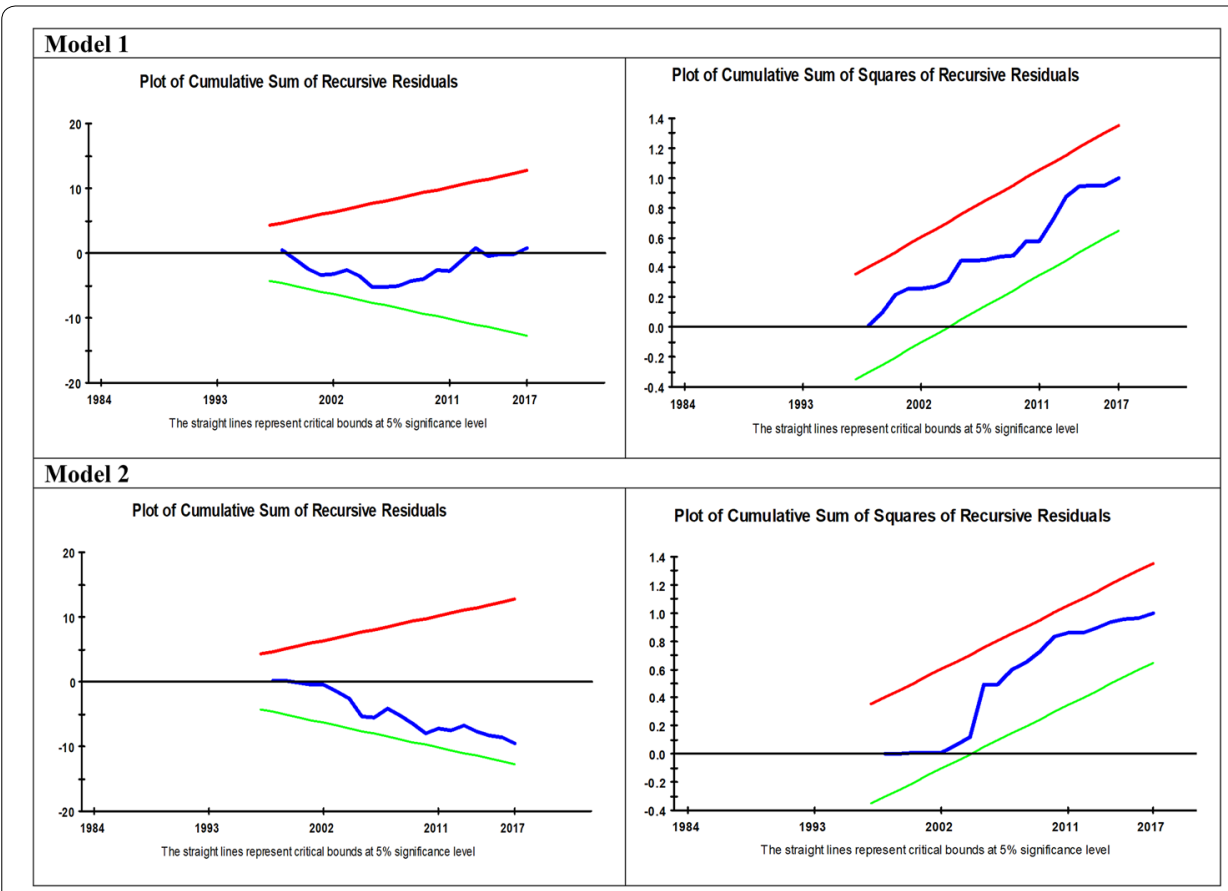

Fig. 1 CUSUM and CUSUMQ Results for Models 1 and 2

\section{Conclusion and recommendations}

In this study, the impact of remittance on poverty was investigated using annual timeseries data from 1980 to 2017, for Botswana. The study employed the ARDL bounds testing approach to investigate the relationship. In an effort to capture poverty in its multidimensional form and to improve the robustness of the results, the study employed two poverty proxies, namely: household consumption expenditure and infant mortality rate. The findings from this study confirmed that remittance reduces poverty irrespective of the time considered when poverty is measured by infant mortality rate. However, remittance was found to be insignificant when poverty is measured by household consumption expenditure. Based on these findings, it can be concluded that the impact of remittance on poverty is sensitive to the poverty proxy employed. Remittance plays a crucial role in reducing health poverty, as confirmed by the significant impact of remittance on poverty when measured by infant mortality rate. However, according to these results, remittance is not effective in reducing income poverty as confirmed by an insignificant relationship between remittance and poverty measured by household consumption expenditure. It is, therefore, recommended that Botswana continue to put in place policies that support remittance inflow as poverty mitigating factor besides it being a solution to unemployment.

\section{Abbreviations}

SDG: Sustainable Development Goals; ARDL: autoregressive distributed lag; ECM: error correction model; ODA: official development assistance; UNICEF: United Nations International Children's Emergency Fund; UNCTAD: United Nations Conference on Trade and Development; HDI: human development index; UNDP: United Nations Development Programme; GDP: gross domestic product; CPI: consumer price index; HHC: household consumption expenditure; INFA: infant mortality rate; EDU: education; TOP: trade openness; GDPC: real gross domestic product per capita; INF: inflation. 


\section{Acknowledgements}

Not applicable.

\section{Authors' contributions}

The authors worked jointly to come up with the paper. Both authors read and approved the final manuscript.

\section{Funding}

Not applicable.

\section{Availability of data}

Dataset analysed in this study is available from the corresponding author on reasonable request.

\section{Competing interests}

The authors declare that they have no competing interests.

Received: 26 August 2019 Revised: 28 October 2019 Accepted: 6 November 2019

Published online: 15 November 2019

\section{References}

Abdulnasser H-J, Salah GU (2014) On the causal nexus of remittance and poverty reduction in Bangladesh. Appl Econ 46(4):374-382

Abosedra S, Shahbaz M, Nawaz K (2016) Modeling causality between financial deepening and poverty reduction in Egypt. Soc Indic Res 126(3):955-969

Acosta P (2008) What is the impact of international remittance in poverty and inequality in Latin America? World Dev 36(1):89-114

Adam RH Jr, Cuecuacha A (2013) The impact of remittance on investment and poverty in Ghana. World Dev 50:24-40

Adam S, Klobodu EKM (2016) Remittance, regime durability and economic growth in Sub-Saharan Africa (SSA). Econ Anal Policy 50:1-8

Adam RH Jr, Page J (2005) Do international migration and remittance reduce poverty in developing countries? World Dev 33(10):1645-1669

Akobeng E (2016) Out of inequality and poverty: evidence for the effectiveness of remittance in Sub-Saharan Africa. Q Rev Econ Financ 60:207-223

Anyanwu JC, Erhijakpan AEO (2010) Do international remittances affect poverty in Africa? Afr Dev Rev 22(1):51-91

Azam M, Haseeb M, Samsudin S (2016) The impact of foreign remittances on poverty alleviation: global evidence. Interdisc Approach Econ Sociol 9(1):264-281

Bharadwaj A (2014) Reviving the globalisation and poverty debate: effects of real and financial integration on the developing world. Adv Econ Business 2(1):42-57

De Vries S (2011) UNCTAD Single-year expert Meeting on Maximising the development impact of remittances: mobilising the use of remittances towards poverty reduction and economic and social development through government initiatives: The Philippine experience

Duflo E, Hendry U (2004) Intra-household Resource Allocation in Cote d'Ivoire: Social Norms, Separate Accounts and Consumption. NBER Working Paper 10498 Cambridge MA, National Bureau of Research and Economics

Fuente AD (2010) Remittance and vulnerability to poverty in rural Mexico. World Dev 38(6):828-839

Gaaliche MG, Gaaliche M (2014) The causal relationship between remittance and poverty reduction in developing countries using a non-stationary dynamic panel data. Atl Rev Econ Revista Atl Econ 1(1):1-2

Gupta S, Pattilo CA, Wagh S (2009) Effects of Remittance on poverty and financial development in Sub-Saharan Africa. World Dev 37(1):104-115

Hagen-Zanker J, Himmelstine CL (2016) How effective are cash transfers in reducing poverty, compared to remittances. Soc Policy Soc 15(1):29-42

Kaidi N, Mensi S, Ben Amor M (2018) Financial development, institutional quality and poverty reduction: worldwide evidence. Soc Indic Res p 1-26

Kapur D (2004) Remittance: the new development Mantra? G24 Discussion Paper 29

Lim S, Simmons OW (2015) Do remittance promote economic growth in the Caribbean community and common market? J Econ Bus 77:42-59

Makun KK (2018) Imports, remittance, direct foreign investment and economic growth in Republic of the Fiji Islands: an Empirical analysis using ARDL approach. Kasetsart J Soc Sci 39:439-447

Meyer D, Shera A (2017) The impact of remittance on economic growth: an econometric model. Economia 18:147-155

Migration Policy Institute (2004) Country Profile Articles. https://www.migrationpolicy.org. Accessed 27 Apr 2019

Migration Policy Institute (2019) Migration Data Portal. https://migrationdataportal.org. Accessed 4 May 2019

Mohr P, Fourie L (2008) Economics for South Africa students, 4th ed. Van Schaik Publishers, South Africa

Nahar FH, Arshad MNM (2017) Effects of remittance on poverty reduction: the case of Indonesia. Jo Indones Econ Bus 32(3):163-177

Odhiambo NM (2009a) Finance-growth-poverty nexus in South Africa: a dynamic causality linkage. J Socioecon $38: 320-325$

Odhiambo NM (2009b) Electricity consumption and economic growth in South Africa: a trivariate causality test. Energy Econ 31(2):635-640

Perron P (1997) Further evidence on breaking trend functions in macroeconomic variables. J Econometrics 80(2):355-385

Pesaran MH, Shin Y, Smith R (2001) Bounds testing approaches to the analysis of level relationship. J Appl Econom 16(3):174-189

Ratha D (2007) Leveraging remittance for development. Migration Policy Institute, World Bank, Washington, DC 
Ratha D, De S, Yameogo ND, Plaza S, Ju Kim E (2018) Migration and Remittances Brief 30

Ravallion M (2001) Growth, inequality and poverty: looking beyond averages. World Dev 29(11):1803-1815

Solarin SA, Shahbaz W (2013) Trivariate causality between economic growth, urbanization and electricity consumption in Angola: cointegration and causality analysis. Energy Policy 60:876-884

Tsaurai K (2018) The impact of remittance on poverty alleviation in selected emerging markets. Compar Econ Res 21(2):51-68

UNCTAD (2019) UNCTAD statistics. https://unctad.org. Accessed 28 Apr 2019

UNDP (2019) Human development reports. https://hdr.undp.org. Accessed 1 May 2019

UNICEF (2019) migration profiles. https://esa.un.org. Accessed 31 Apr 2019

United Nations (2019) Sustainable Development Goals, https://sustainabledevelopment.un.org. Accessed 18 June 2019 Vacaflores DE (2018) Are remittances helping lower poverty and inequality levels in Latin America? Q Rev Econ Financ 68:254-265

Van Multzahn R, Durrheim K (2008) Is poverty multidimensional? A comparison of income and asset based measures in Southern African countries. Soc Indic Res 86(1):149-162

Wangle UR, Devkota S (2018) The impact of foreign remittance e on poverty in Nepal: a panel study of household survey data 1996-2011. World Dev 110:38-50

World Bank (2019) World Bank Development indicators. https://databank.worldbank.org. Accessed 24 Jan 2019

Yasman I, Hussain Z, Akram W, Yasman N (2015) Bidirectional causality between remittance and poverty: an empirical investigation from Pakistan. J Econ Sustain Dev 6(24):176-183

\section{Publisher's Note}

Springer Nature remains neutral with regard to jurisdictional claims in published maps and institutional affiliations.

\section{Submit your manuscript to a SpringerOpen ${ }^{\circ}$ journal and benefit from:}

Convenient online submission

- Rigorous peer review

- Open access: articles freely available online

- High visibility within the field

Retaining the copyright to your article

Submit your next manuscript at $\boldsymbol{\Delta}$ springeropen.com 